\title{
Balkanologie
}

Balkanologie Revue d'études pluridisciplinaires

Vol. XIV, $n^{\circ}$ 1-2 | 2012

Volume XIV Numéro 1-2

\section{The Two Carnegie Reports: From the Balkan Expedition of 1913 to the Albanian Trip of 1921}

A Comparative Approach

\section{Nadine Akhund}

\section{OpenEdition}

\section{Journals}

Édition électronique

URL : http://journals.openedition.org/balkanologie/2365

DOI : 10.4000/balkanologie.2365

ISSN : 1965-0582

Éditeur

Association française d'études sur les Balkans (Afebalk)

Référence électronique

Nadine Akhund, «The Two Carnegie Reports: From the Balkan Expedition of 1913 to the Albanian Trip of $1921 »$, Balkanologie [En ligne], Vol. XIV, n 1-2 | 2012, mis en ligne le 06 février 2013, consulté le 17 décembre 2020. URL : http://journals.openedition.org/balkanologie/2365 ; DOI : https://doi.org/ 10.4000/balkanologie.2365

Ce document a été généré automatiquement le 17 décembre 2020.

(c) Tous droits réservés 


\title{
The Two Carnegie Reports: From the Balkan Expedition of 1913 to the Albanian Trip of 1921
}

\author{
A Comparative Approach
}

\author{
Nadine Akhund
}

1 From the Balkan Wars to the end of World War One, international relations changed thoroughly. This shift in depth was the final phase of an evolution that started between the Crimean War and the Berlin Congress of 1878. At the same time, a broader movement was emerging: the Peace Movement, whose premise was that war was not going to disappear but the rules of war should be codified through international law. The Peace movement also addressed new concepts such as the issues pertaining to civilians in wartime. As a corollary, prevention of conflict, collective intervention might contribute to defuse crises and dissipate tensions. These concepts slowly made their way to the highest foreign offices of the European Great Powers and in the USA through conferences, several of them organized at the Russian initiative ${ }^{1}$. Then, the well-known two Hague conferences of 1899 and 1907 constituted the first try to provide institutions to the Peace Movement as the Great Powers gathered among more than 20 other states to discuss world issues ${ }^{2}$.

2 This evolution in foreign affairs was particularly noticeable in the Balkans during the decline of the Ottoman Empire. Along the $19^{\text {th }}$ century, the region can be viewed as a laboratory of political experiences ranging from classic military intervention, invasions (the Ottoman point of view), or wars of liberation for the Balkan states, to a range of intermediary political tryout such as the occupation of Bosnia-Herzegovina or the complex autonomous status of Bulgaria. Of these, international intervention is to be highlight, as it would have a major impact on foreign international policy during the $20^{\text {th }}$. In the Ottoman Empire, international intervention derived from the Great Powers' involvement which took various forms, such as military, Austrian or Russian armies, or protection of the Christian orthodox minorities and led around 1878 to the establishment of zones of influences, the Great Powers division of the Balkans among 
themselves, following their rising recent economic interests ${ }^{3}$. Around 1900, international intervention ceased to be based on marching armies and instead collective diplomacy emerged as a response to the crises linked to the rise of nationalism and the decline of the central power in Istanbul. The first organized international interventions took place in Crete 1899 and in Macedonia in 1904 ${ }^{4}$.

What could be the link between the Peace Movement, the evolution in foreign affairs and the well-known philanthropist Andrew Carnegie (1835-1919) ? Carnegie, like others successful entrepreneurs of the time, supported the Peace Movement as peace implied economic prosperity and progress for the humankind; and war meant regression ${ }^{5}$. Founded in 1910, the Carnegie Endowment for International Peace (CEIP) had three objectives: to promote international understanding, to study the effects of war on civilians, and to support international law. Carnegie surrounded himself with leaders belonging to the new professional class, lawyers, academics and diplomats. They were the products of urbanization and industrialization that accelerated since the end of the US Civil War. Mostly Protestant, Republican and conservative, they believed that education could shape public opinion. The CEIP was run by a board of trustees that usually met twice a year to discuss budget and programs among the three divisions of international law, inter-course and education and economics and history ${ }^{6}$. Carnegie appointed individuals he knew through business, friends he trusted on a personal level. For the period under study, the main personalities were Elihu Root (1845-1937), his lawyer, the first president of the CEIP until 1925, Nicholas Murray Butler (1862-1947), a key personality, president of Columbia University from 1901 to 1945 and later second president of the CEIP, James Brown Scott (1866-1943), international lawyer and head of the division of International Law, James Shotwell (1874-1965), History Professor at Columbia University and head of the division of Economics and History. The CEIP was also a trans-Atlantic and transnational network with strong connections in Europe thanks to US diplomats such as Andrew White (1832-1918), a former ambassador in Germany and Russia, head of the US delegation at the Hague Conference of 1899, and Charlemagne Tower Jr. (1848-1923), also former ambassador in Germany, Russia and Austria-Hungary. In Europe, a close network of academics and diplomats were members of the CEIP European bureau, created in Paris in 1912, under the direction of another key player, Paul d'Estournelles de Constant (1852-1924), a French diplomat and a personal friend of Nicholas Butler.

How was the US-based CEIP drawn into the explosive situation in the Balkans at the time of the final chapter of the Eastern Question? The Carnegie Endowment intervened in the Balkans in 1913 and again in 1921. Because the Endowment sent an international commission to have an impact on international policy, this paper describes how the two Carnegie reports constituted an international intervention of a new kind, as it was not mandated by any of the Great Powers. By sending delegates in the Balkans, the CEIP, as a new comer, a non-governmental organization was present at the dawn of a new type of international relations after 1918.

1.

\section{Narrative of the two reports of 1913 and 1921}

5 The explosive situation in the Balkans was the perfect opportunity for the Carnegie men to apply the principles they had been defending for several years.

1. 1. 


\section{A. The Balkan Expedition of 1913}

6 On July 21, 1913, Nicholas Butler wrote to his longtime friend Paul d'Estournelles de Constant: "The time has come to send a notable commission, without a day unnecessary delay, to the Balkan States in order that they might see for themselves just what the conditions are and make a report to the Trustees of the Carnegie Endowment (...) which might be sent broad-cast all over the world $»^{7}$. Further in his letter, Butler defined the following objectives of the future commission: to establish the truth about the massacres and atrocities; to look for those responsible for the outbreak of the wars; to define the moral and economic losses of the war and the lessons for "the civilized people"; and finally to conduct an impartial study of the facts observed in the field. The essential role of Nicholas Butler as sole decision maker is to be underlined. Butler informed Elihu Root on July 19 and then wrote to d'Estournelles de Constant about his decision. On July 17 and 18, 1913, the New York Times published two long articles on the King of Greece's graphic reports of massacres committed by Bulgarian troops against civilians. In his letter to d'Estournelles de Constant, Butler quoted extensively the two articles ${ }^{8}$. Andrew Carnegie himself was not consulted. While in Scotland, he learned about the commission few weeks later through a British newspaper and he wrote: "I confess that I got a shock", asking d'Estournelles de Constant to provide information about it ${ }^{9}$. In fact, Carnegie did not approve the concept entirely, commenting that an inquiry would antagonize further the conflict.

7 The Balkan expedition took place at the end of the Second Balkan war. The Balkan wars were short, less than a year long (October 1912-August 1913), extremely bloody and set a precedent in the new century for the massive atrocities on every single side ${ }^{10}$. Moreover, the wars ended five centuries of Ottoman rule in Europe. What were the reasons for the Carnegie Endowment to intervene and to set up an inquiry in a Balkan regional conflict? From the outset, the "Carnegie men" were concerned with the treatment of civilians in warfare. In 1912-13, the civilians represented a crucial stake as each Balkan state was driven by the concept of one nation within one state. The wars were extensively reported in the European and in US presses. A flurry of articles emphasized the magnitude of atrocities raising polemics about the belligerent's responsibilities. As Butler wrote, the press speculated on why the Endowment was not denouncing the massacres.

8 From Butler's letters until mid-August, when the commission was formed, few elements revealed his visionary sense of modernity providing the structure of the future report. The commission should be an international one. While Butler suggested and exchanged names with d'Estournelles de Constant, he insisted on including a German and an Austrian. In addition to American, Britons, and French, others nationalities were considered: Italian although briefly along with Argentinean, Hungarian but discarded, and Russian retained ${ }^{11}$. No Scandinavians were mentioned where they were already part of police forces in Crete and Macedonia (military from Sweden, Norwegian, Belgium). Butler insisted on choosing prominent people, as he wanted as much publicity as possible and to use the press on a wide scale to advertise one of the main the CEIP objective, to denounce the horrors of the wars. «It will be of vital importance to use all possible publicity for this commission and its work ${ }^{12}$..According to Butler, public opinion was regarded as a potential actor that needed to be informed and educated to prevent further conflicts. In fact, the education of the public was one of the Endowment's major objectives ${ }^{13}$. Finally, the timing was also important. Butler wanted 
the commission to almost witness the massacres in order to be in better position to denounce them. He insisted on an almost immediate departure: three weeks on the ground and a report ready by September 1913.However, the constitution of the commission took much longer than Butler had expected. As primarily a network in essence, the CEIP relied on personal link. The members of the commission were chosen on the basis of their friendship with either Butler or d'Estournelles de Constant. Eventually, the commission grew larger and it was decided to split it, with a group staying in Paris and the other one going to the Balkans ${ }^{14}$. Three members were university professors, three other representatives of their parliament and two were journalists. The commission included eight members under the presidency of d'Estournelles de Constant: Paul Miliukov, historian and member of the Duma, the British journalist Henry Brailsford, Francis Hirst, editor of The Economist, and the American law professor Samuel Dutton ${ }^{15}$. Justin Godard, a French deputy of Lyon, was appointed secretary to the commission. Finally, Law Professor Walter Schücking from Marburg and Professor Joseph Redlich from Vienna joined the commission. Most of the members already knew each other ; Redlich was a friend of Hirst ${ }^{16}$.

The trip lasted from August 20 to September 28. The members traveled through Vienna, to Belgrade, Salonika, Athens, Constantinople, Sofia, and back to Paris. It was a challenging time for such an expedition, as the Treaty of Bucharest ending the wars, had just been signed on August 10. Summarizing the spirit of the inquiry, Samuel Dutton wrote: "the opportunity of gathering materials for new and most impressive propaganda against war is unique $\aleph^{17}$. Due to various issues and to great disappointment of Butler, the commission was reduced to four members on the ground after reaching Belgrade. Hirst had declined to travel for family reasons. At the last minute, Redlich was not authorized by his government to travel and Schücking, because of German authorities' reluctance, joined later. Upon his arrival in Serbia, he was told that the trip had been cancelled and he went back to Germany. The interference of the German and Austrian governments surprised Butler, for whom universities, as private institutions, and their faculty were expected to remain independent from government influence ${ }^{18}$. However, later the three men were fully involved in the writing of the report. Obviously, time for preparation had been short, the Ottoman and Balkans authorities were notified late, the commission was stopped and delayed several times. Paul Miliukov was stopped in Belgrade while Henry Brailsford had his own administrative troubles in Greece. However, they approached their assignment as fieldwork, and despite the fact that only Brailsford and Miliukov understood some slavic languages, they sought to collect evidence for their investigation and conducted extensive interviews on all sides, gathered information and evidence of tortures from civilian witnesses and victims, inspected destroyed villages, religious sites (churches, mosques) and mass graves ${ }^{19}$. Upon their arrival in Sofia in September 1913 Professor Dutton wrote: "What an experience : I sometimes feel as though I had been standing on the brink of Hell $»^{20}$.

Upon their return, the Balkan commission held several meetings in Paris and it was decided that Miliukov would write four chapters, Brailsford, Godart and Dutton one chapter each ${ }^{21}$. Unfortunately, the publication was delayed by more than six months, essentially because Paul Miliukov was unable to finish his chapters before April 1914 to the great exasperation of Butler who insisted on the " psychological moment, both here and abroad » not to be missed ${ }^{22}$. The writing process added to the delay, Miliukov wrote in French as well as Godard while Hirst and Brailsford supervised the translation in 
English. Then, the finished work was sent to the US for correction and transliteration of Slavic names while the maps and photos were printed in the US and sent to France for the French edition. Butler insisted on having the French and in English versions released on the same day. A German translation had been planned but did not occur because of the delays ${ }^{23}$. Finally in May, a press release was sent to about 1250 newspapers advertising the report ${ }^{24}$. Most of the volumes were sent upon request, as it was a non profit-driven operation. The reactions and critics in the press were mixed, the Balkans government's protests were strong, but all of them were rapidly overshadowed by the outbreak of the war.Butler's fears turned to be right, the momentum was partly missed. However, the Carnegie report was exceptional for his time. Because the report focused almost exclusively upon the conditions of civilians during the Balkans wars, it advocated, perhaps idealistically, that international law might prevent or limit atrocities in the future. By choosing to advertise the Balkan Report, Butler assigned public opinion a new role. For the first time, a group of influential people believed that it could affect the ruling of international affairs. The Carnegie report questioned if the massacres of civilians had been committed by armies representing their governments or by nations to annihilate ethnic groups in the name of nationalism. The report denounced the behavior of all belligerents: the Montenegrins tried to convert or kill Albanians. The Greek and Serbs efforts to "Hellenize", "Serbianize" people in Macedonia and the Bulgarian trying the opposite. A new range of vocabulary appeared: war of extermination, deportation, campaign of murders, torture of the war prisoners, violence against women and children, refugee camps etc. The report also denounced the Great Powers policy, «these unhappy Balkans states have been until now much more the victims of the European decisions than of their own faults ${ }^{25}$, underlining that the Balkans people were never consulted in the previous international agreements, from Berlin to Mürzsteg. Overall, the report denounced the "secret diplomacy" and advocated what would be today termed "transparency" in politics.

1. 1.

\section{B. The Albanian trip of 1921}

11 Seven years later, d'Estournelles de Constant reopened the Balkan inquiry to follow up with the one of 1913. The Carnegie trip to Albania was the final in a series of initiatives and actions taken by d'Estournelles de Constant to defuse the international crisis over the status of Albania. The international landscape was entirely different, as war modified not only the geo-political map of Europe but also spirits and minds in foreign policy. In an innovative way, as soon as the war ended, the Carnegie Endowment promoted international reconciliation. Further, the CEIP undertook a large reconstruction program for universities and public libraries ${ }^{26}$. It also addressed the issue of rebuilding relationship with Germany and discussed the new political map of Central and Southeastern Europe at conferences. Soon enough, the Balkans attracted once more the attention of the CEIP leaders from two angles. First, Albania was an international issue. Born in December 1912, invaded, occupied and partitioned during the war, Albania appeared barely as a survivor in the post-war context. Its fragile conditions appealed to the CEIP Balkan Commission. Second, the League of Nations (LN), newly created in 1920 was involved in the intense debate over the international recognition of Albania. A convergence of interests is to be noticed as the League's of Nations French delegation was located in the Carnegie Endowment offices in Paris with 
Butler's agreement ${ }^{27}$. The CEIP secretary, Jules Prudhommeaux (1864-1948), was also the one of the LN's French delegation presided over by Leon Bourgeois, a friend of d'Estournelles de Constant and Butler. Finally, Bourgeois was a member of the consultative committee of the Paris CEIP and was highly appreciated by Elihu Root ${ }^{28}$.

From the Carnegie archives it appears that according to Butler and d'Estournelles de Constant, the Balkan report of 1913 needed to be completed. Both men viewed it as the first part of a larger project and/or, they were thinking of another study to follow in an unknown future ${ }^{29}$. As soon as the war ended, criticism of the report re-emerged. In May 1919, Greek representatives at the Peace Conference approached the Paris Carnegie office asking to modify some conclusions of the 1913 report $^{30}$. On the Greek side, Venizelos, then prime minister, sent a representative - Professor A. M. Andreades - in the US, where he met Butler ${ }^{31}$. The Swiss Law Professor Archibald Reiss, known for his pro-Serb positions, was also contacted separately from the Greeks, and Justin Godart from the CEIP ${ }^{32}$. In the end, Butler and d'Estournelles de Constant rejected the GreekSerbian request but discussed the possibility of sending a second commission along with another one, to be sent in Russia to inquire into Bolshevism. However, it appeared that the reconstruction program was a higher priority than an investigation on massacres that had happened six or seven years previously ${ }^{33}$.

The political situation in Albania was highly complex. The country was a stake for Greece, Italy and Yugoslavia, which were putting pressure on France and Great Britain at the Peace Conference to partition the state among the three of them as planned in the 1915 London Treaty. Following President Wilson's opposition and a short Albanian revolt in Vlorë, a port city that was supposed to become Italian, Italy renounced to its territorial ambitions. However, since the borders with Greece and Yugoslavia remained undetermined, violent incidents erupted in two contested areas during the summer of 1920 and until 1921. In the north, in the area between Shkodër and Debar (the Drin Valley), Yugoslav troops entered into Albanian territory and raided villages, an allegation denounced by Belgrade according to which the Albanians initiated first a border incidents ${ }^{34}$. In the south, around Korçë and Gjirokastër, the Greek minority complained about a "persecution campaign" and found echo and support from Athens ${ }^{35}$; this was the sensitive question of Northern Epirus versus Southern Albania. The Carnegie archives contain detailed reports on the situation in Albania as d'Estournelles de Constant received regular news through the Albanian delegation at the Peace Conference, including Mehemet Konitza (1881-1948), the head of the Albanian delegation, and Midhat Bey Frashëri (1880-1949), later Albanian representative at the League of Nations ${ }^{36}$. In this context, d'Estournelles de Constant decided to take a double initiative toward the Balkan state he called the "Cinderella of the Balkans".

14 First, at the end of the summer 1920, he wrote to Milenko Vesnić in Belgrade and Venizelos in Athens, both of whom he knew very well ${ }^{37}$. In two personal letters, he denounced the attacks against a nation whose rights to exist were denied, arguing that he took the cause of Albania in the same way that he had previously defended Serbia and Greece ${ }^{38}$. Two days later, he also sent an appeal at the highest level to Lloyd George, Wilson and Balfour, as well as to Millerand, Giolitti, Paleologue and Berthelot, denouncing what he called "the extermination of the Albanian people $»^{39}$. Later, he followed up with telegrams sent to Hymans, Bourgeois, Viviani, Hanotaux and Balfour ${ }^{40}$. Adopting a cautious attitude, d'Estournelles de Constant did not act in the 
name of the CEIP, but as a politician state-man and an activist of the Peace Movement. However, he was obviously known for his official position as President of the Paris Endowment's office. He shared his initiatives with Butler and reported regularly about his actions, asking him to keep the CEIP trustees informed as well.

On December 17, 1920, after two negative votes, Albania became a member of the League of Nations ${ }^{41}$. D'Estournelles de Constant attributed this success to his multiple letters and unofficial meetings, emphasizing the weight of his personal networking activity, even describing the officials of the Quai d'Orsay, the French Foreign Affairs minister, as an elite of his closest colleagues which he had personally formed and educated in the past ${ }^{42}$. In an emotional letter to Butler, d'Estournelles de Constant wrote : «I have the honor to announce the birth of a child of whom I am not the father but the godfather $»^{43}$.Without minimizing the role of d'Estournelles de Constant as president of the CEIP Paris office, one has to put his policy in perspective, as he was not the only defender of Albania. In London, a strong influential political network led by Lord Robert Cecil and Aubrey Herbert was equally eager to have Albania joining the League $^{44}$.

Despite the admission of Albania at the League of Nations, the situation on the ground did not improve. The territorial integrity and the borders issues remained unsolved as Greek and Serb-Yugoslavs armed bands continued to maintain a high level of violence. D'Estournelles de Constant took then a second step. In a letter from March 22, 1921, he informed Butler that Albanians officials invited him to go to Albania ${ }^{45}$. Because of his age, his functions as senator, his known pro-Albanian position and his involvement in the CEIP reconstruction program, d'Estournelles de Constant declined the invitation but decided to send Justin Godart to complete the inquiry process started in the Balkans in 1913. Justin Godart (1871-1956), a member of the French National Assembly, is mentioned in the Carnegie archives as member of the advisory council and later as vice-president of the Paris office. In 1924, after d'Estournelles de Constant's death, he was considered as his potential successor at the head of CEIP Paris office. Even if he was twenty years younger than d'Estournelles de Constant, the two men became extremely close friends as d'Estournelles de Constant choose him as French representative in 1913 and asked him to go to Albania in 1921. The trip had a double objective : first, to defend Albania as a viable state and its territorial integrity; and second, to persuade France, Great Britain and USA to recognize Albania.

17 The trip was entirely, personally and carefully planed by d'Estournelles de Constant. Godart left Paris on March 21 and came back on May 24, 1921. What were the main features of the trip ? Godart was traveling with only one companion, Prothiere, keeping a low profile and being cautious not to provoke reactions or protest from Yugoslavia and Greece. D'Estournelles de Constant even decided against advertising the trip in the press $^{46}$. Godart went through Rome where he met the Italian foreign minister, Count Sforza and the French ambassador Camille Barrère. He reached Durrës at the beginning of April and made two separate trips into Albanian territory. The first one was toward the north up to Shkodër and went back to Durrës, and the second was toward the south to Berat, Vlorë, Gjirokastër. From there he made his way back along the Greek and Yugoslav borders, stopping at Korçë, Ohrid, Elbasan and Tiranë. Along the trip, Godart was always escorted by the Albanian authorities. The travel conditions were occasionally difficult because of the poor shape of the roads. Most of the trip was done by car but Godart recalled riding horses along the lake of Ohrid on their way to Elbasan. 
Surprised by the heavy rain and the night, the group had to sleep over at the home of a retired Albanian officer ${ }^{47}$.

Upon his return, Godart wrote a substantial report ${ }^{48}$. In January 1922, the volume was published in Paris by the CEIP and the University Press of France (PUF) ${ }^{49}$. The eleven chapters report covers three majors areas, the history of Albania centered on the genuine existence of the Albanian people, the current conditions (political structures, economy and resources) and a political analysis of the regional situation and the relations with the neighboring states of Italy, Greece and Yugoslavia. The report reflects the extreme personal vision of Godart and makes a four-point argument. First, Albania is a victim of the territorial ambitions of its neighbors and the Great Powers' policy is denounced as vigorously as it was in the 1913 report (chapter 5). Second, the damages inflicted by the wars are meticulously described and the responsibility for the borders crisis attributed equally to Greece and Yugoslavia (chapters 7 and 8). Third, Godart emphasized the reality of the national consciousness (chapter 4) the solidity of the Albanian institutions recognized by all inhabitants. He insisted on the perfect harmony and peaceful conditions throughout most of the country even referring to Albania as "the Switzerland of the Balkans ». In fact, the internal political situation was quite tense and unstable. The two political leaders, Fan Noli and Ahmed Bey Zogu were struggling against each other to size power and the institutions were barely functioning. Godart's one-sided vision of Albania tends to limit the credibility of the report and of the inquiry supposed to be conducted with impartiality. Finally, Godart is raising the following major issue, which is probably the core of the report: does an international organization such as the League of Nations have the competence to decide on the status of a state? In other words, could the League of Nations rule on international affairs and decide or impose the international recognition of Albania? According to Godart, d'Estournelles de Constant and the CEIP, it could.

1.

\section{A Comparative Approach : Continuity and Rupture}

19 The two reports took place at two crucial turning points in European international affairs. The first looms up at the twilight of the Great Powers's Empires. The second appears at the onset of a new area as international affaires were from then on placed under the umbrella of international organization, a concept that will dominate the $20^{\text {th }}$ century foreign affairs.

1. 1.

\section{A. Continuity}

The records in the Carnegie archives clearly establish how the report of 1921 continues the one of 1913. The link and the filiations appear numerous times in the correspondence between Butler and d'Estournelles de Constant and in the two prefaces of the reports. "Once the Great War was over, it seemed to me that our report of 1913 ought to be completed», wrote d'Estournelles de Constant in $1921^{50}$. Despite the war and seven years, the settlements of the Eastern Question were still of great importance in foreign affairs. For the Carnegie men, there was a need to reopen the Balkan file as well as to find a way to address the critics that resurfaced in 1919. As d'Estournelles de Constant put forward, Albania has been left out from the 1913 inquiry. Justin Godart as member of the international commission of 1913 and as a sole traveler in 1921 is the 
common thread between the reports, both carried out in the name of the Carnegie Endowment.

21 The format of the reports is similar : an inquiry, an investigation guided by the concern to establish the truth as seen on the ground. Despite the proliferation of articles, information reported by the press appeared in 1913 and in 1921 as fragmentary, distorted and contradictory. In both cases, to a certain extent, the press initiated the inquiries. The Balkan wars were amongst the first military conflicts reported on such high scale by the press, although the process started during the previous ones in the region, the Crimean War, later the Russian Turkish and the Greek Turkish wars. In 1921, the Albanian borders issues were not making headlines in the press more preoccupied by the postwar treaties, but the idea of establishing the truth from one own eyes appear equally in the two reports. For the Carnegie men, the corollary to the idea of establishing the truth was that this inquiry was to be conducted with impartiality and objectivity. These words were used repeatedly on both sides of the Atlantic. Butler defined the inquiry as an impartial examination by an independent authority. However, both reports suffered from the same weakness that led to the same critic. The choice of the participants was highly personal due to the friendly nature that prevailed in the relationship amongst the CEIP leadership. From the beginning, Miliukov, recommended by "our friend"Kovaleski, and Brailsford recommended by "his friend" Hirst, never concealed their openly pro-Bulgarian positions, but obviously their opinions limited or even discredited the content of some aspects of the reports as Athens and Belgrade used their one-sided opinion to protest ${ }^{51}$. In the same way, the strong anti-Serb and anti-Greek's features shown by Godart, probably influenced by his mentor, d'Estournelles de Constant, limit the credibility of his writing and the facts he reported. However, despite their personal points of view, the inquiry members in 1913 and 1921 made the point not only to gather but also to confront information from all sides, allowing them to maintain a certain degree of objectivity ${ }^{52}$. In 1921, Godart blamed equally Athens and Belgrade for their territorial ambitions toward lands he saw as truly Albanian.

The exhaustive two prefaces, approximately 25 pages long and both written by d'Estournelles de Constant, are another common element of the two reports. Both represented his personal touch expressing his point of view written on a vivid tone. Starting with a strong statement, d'Estournelles de Constant speaks out to the reader as a witness, an interlocutor, using direct, strong sentences : «I owe a lot to Albania and I will pay back this debt of my youth » are the first words in 1921 (original text in French). "War rather than slavery, arbitration rather than war, conciliation rather than arbitration » open the 1913 report. Both texts are conceived following the same path offering an elaborate description of the context (the Balkans Wars, history of Albania) and the reasons for the Carnegie involvement. Then, a summary of the trip explains the organization, the personalities of its participants and how both reports were later written. The vocabulary is similar, using words such as "truth", "impartiality" or "objectivity"53. In both texts, d'Estournelles de Constant put forward the weaknesses, the obstacles, and the difficulties encountered, as well as the protests from the Balkans states, the tensions with Belgrade and Athens in 1913 and in 1921. He was also very aware that no one was going to be pleased by the reports and was ready to face criticism although he was convinced that ultimately his vision of international affairs, the need for international law and new rules in warfare would prevail. 

approach or a field approach, the wars and the massacres were viewed as an object of study. The inquiry members went in the field at a time the events were almost happening. They wanted to ascertain by themselves the facts and record them with accuracy as in both cases translators were involved (only Miliukov and Brailsford knew Slavic languages). As Butler emphasized, in a straightforward sentence, the inquiry «represents the first instance in history of a study of the results of war by the laboratory method" and further he also insisted on "the inductive method of observation $»^{54}$. A range of modern tools was used to provide a systematic and analytical recollection of the facts : statistics, demography, figures as well as photos taken in action illustrate the will to be as accurate as possible. In 1913, the report included twenty pages of detailed statistics. Each village, small town visited by Godart include a meticulous description of the demography, the city budget and an elaborated list of the prices of the everyday life food and goods along with a conversion in French Francs.

The importance of economy is underlined in both reports. Studying the economy and its impact on the evolution of the society was one of the main features of the Carnegie Endowment from its very origins. One of the three divisions called Economy and History was in fact entirely centered on the influence of economy on historical developments. The weight of the economy appears in both reports from two angles. First, the reports assessed the amount of economic damage inflicted by the wars. The 1913 report includes a detailed chapter (chapter 6) written by Samuel Dutton, on the economic consequences of the wars in terms of destruction of the infrastructures (roads, bridges), the industry (factories) and the agriculture. He also insisted on the impact of the war on the national revenues of each Balkan state and how people deposits in saving banks went down ${ }^{55}$. In 1921, Godart described in details the poor conditions of the cattle and farmlands. Moreover, both reports provide a complete financial analysis, a description in depths of the banking situation, the national debt, tax system, and the cost of the war (war material, cost of ammunition, equipment of the army, etc.). The refugees and displaced people are also included in the financial general statement and not only within regards of their rights in warfare. Second, the close link between economy and wars made by the CEP leadership is also discussed in the archives. The first mention of an inquiry appeared in 1912 under the elaborated temporary title: "A statement as complete and objective as possible on the losses in terms of men and money caused by the war in the Balkans $"^{56}$. The II division was then considered to be put on charge of the inquiry. According to the Carnegie men, economic prosperity was perceived as a guarantee of peace, as well-off people would be less tempted to kill each other.

Both reports offer a statement on the necessity for an international organization whose competence and authority should be above those of any state. In 1913, the chapter 5, entitled "The war and international law ", referred to the two Hague Conferences and to the constitution of a permanent international commission to regulate the laws of war. In 1921, the chapter 9 entitled «Albania and the League of Nations " is entirely focused on the definition of the role of the League of Nations and its possible expansion in the future. In both cases, the traditional Great Powers's policy in the Balkans (military invasion or zone of influences) is denounced. In 1921, Godart criticized the conference of the Ambassador ${ }^{57}$ on charge of the borders delimitation, as a symbol of 
the continuation of this policy, the pre-war international order, which ignored the real interests of the Albanian people ${ }^{58}$.

Finally, one theme largely dominates the two reports : what should the features and meanings of an international intervention be ? Since the 1913 commission was truly an international one with six nationalities represented, and the 1921 commission included only French delegates, the following point constitutes a transition between continuity and rupture between the two reports. Both of them reflect the spirit of the international mind, a concept elaborated by Butler around $1907^{59}$. One can draw a line between the two Carnegie reports and a series of conferences given by Nicholas Butler from 1907 to 1912 and gathered in the book The International Mind: an Argument for the Judicial Settlement of International Disputes (1912). The international mind, as viewed by Butler and the Carnegie leadership, born out from the Peace movement and The Hague Conferences, is an attempt to redefine rules and regulations in international policy in order to transcend nationalism viewed as an outdated stage. For Elihu Root, the CEIP president, "the public opinion of the world is the true international executive power $»^{60}$. In both reports, the major actor is public opinion, first in 1913 as the target of the report, and later in 1921 as an organized institution, the League of Nations. "The International mind is nothing else than that habit of thinking of foreign relations and business (...) » and « regard the several nations of the civilized world as friendly and cooperating equals in aiding the progress of civilization, in developing commerce and industry, and in spreading enlightenment and culture throughout the world $»^{61}$. According to Butler, public opinion should promote this international mind; today, would we call it globalization? Further this public opinion, once informed and educated, has the duty to participate in the ruling of public affairs and by doing so become an active member of the civil society. Both reports illustrate the emergence of the concept of civil society before and after World War One.

1. 1.

\section{B. Rupture}

As d'Estournelles de Constant wrote several times, the CEIP failed to stop the war, a fact he resented greatly once the Great War started and in that sense, the 1913 report fell short of its general objective. In 1921, the CEIP asked the following question : does an international organization have the competence to give a legal recognized status to a new state? Since ultimately Albania was eventually recognized as a state with defined borders in 1925-26, the 1921 report partly reached its objective.

The main differences lay in the circumstances of the two trips. The 1913 trip, at the end of the Second Balkan War, was viewed by the Carnegie leadership as an answer to a humanitarian disaster. The one of 1921 derived from the inadequate settlements or mismanagements in some decisions taken at the Peace Conference. Clemenceau was reluctant to address the Albanian question all together; Wilson and Lloyd George supported the Albanian claims. The issues addressed in the two reports were related as both dealt with the aftermath conditions of war but their immediate objectives were different. The 1913 report denounced war massacres, atrocities and addressed the issues of civilian conditions, casualties and rights during warfare. Further, for the first time, a released document attempted to assign responsibility for the massacres, questioning whether the atrocities had been committed by officers, soldiers following order from their armies or by "armed band" operating semi-independently. In 1921, the report dealt with the issue of the existence, the viability of a state, Albania, its 
borders and advocated for its international recognition. Finally, the role played by the civilians was reported differently. One of the main points of the 1913 documents is to dissociate, to separate the representation of a civilian from the armies during warfare while the report of 1921 dealt with the civilians as responsible and decisive actor within the civil society. The Albanians citizens as civilians would have to organize their state and their national institutions.

The scale of publication constitues another difference between the two documents. The 1913 report was launched as a wide international operation conducted simultaneously on both sides of the Atlantic. Almost 20000 volumes were edited (13 000 in English and 5000 in French). In 1921, the Albanian report was limited to a single French publication on a much lower scale of few hundred volumes. In the same way, the publicity, advertising and the involvement or not of the press were addressed following almost opposite approaches, and illustration perhaps of the different personalities between Butler and d'Estournelles de Constant. In 1913, Butler gave several press communiqués and kept the journalists informed of the progress of the commission whose departure in train from Paris was released with great publicity. He mobilized all possible means of publicity to have an impact on public opinion, a strategy he would use again after the war to advertise the reconstruction program undertaken in Europe with the building of universities and public libraries in Belgrade, Louvain and Reims ${ }^{62}$. According to his own words, «the public opinion of the world is crying out for the light and for leadership in regard to these dreadful happenings in the Balkans $»^{63}$.In 1921, d'Estournelles de Constant simply refused to involve the press and not a word was published about Godart's trip prior to his departure. From the tone of his letters, he was concerned to avoid the same strong, aggressive protest from the Balkans officials that had occurred in 1913. It seems that these critics may have influenced his attitude toward the press in 1920-21. When describing his initiatives to Butler (lobbying, writing to statesmen/ personalities), he insisted on keeping the journalists away ${ }^{64}$. However, once Godart came back and wrote the report, d'Estournelles de Constant organized a large press release to advertise the Albanian report. The role of public opinion evolved between the two reports. The 1913 report is an address to public opinion and to the international audience as such, an appeal to inform and an attempt to educate about the horrors of the war. By 1921, public opinion was then organized, it had a legal recognized frame, that was the League of Nations. As organized institution, the League of Nations would decide the admission of a possible new comer, Albania.

Why did the 1913 report cross over the $20^{\text {th }}$ century and not the one of 1921 ? The answer lay in the scale of publication already mentioned. In addition, the 1913 report dealt with almost the entire Balkan Peninsula where Albania represented a limited and regional stake. Today, the Carnegie report of 1913 is included in numerous books on Balkan History and/or the Eastern Question. Authors such as Mark Mazower, Maria Todorova, Ivo Banac or Micha Glenny refer sometimes extensively to the inquiry ${ }^{65}$. In a paradox, most of these authors include generally descriptions of massacres that had been precisely denounced as false by the Balkan governments in 1913 and in 1921 ; and continue to be, up today, an unsolved issue for several historians of the region. Beyond the atrocities against civilians and the responsibility aspect, the report of 1913 reached the $21^{\text {th }}$ century as a reference, an object of study and of debate for its truly innovative concepts all evolving around the one of how to organize a new kind of international policy and its rules.

1. 


\section{Conclusion}

31 expanded in the following years ${ }^{66}$. Almost immediately after the release of the Albanian report of 1921, Godart took another trip and the CEIP Paris office published another report entitled Albania in 1922. Actually, this shorter publication included mainly the report of the international commission sent by the League of Nations in NovemberDecember 1921. The concept of sending of an international commission whose participants were chosen exclusively from neutral states to guarantee impartiality and objectivity went one step further, as the one sent in Albania in 1922 was composed of members from Finland, Norway and Luxembourg. The initiatives of 1913 and 1921, taken by the CEIP as non-government organization were in that sense innovative. During and after World War One, several investigative commissions were sent to various areas : a French-Belgium-British one to investigate German massacres, a Greek one sent to Macedonia, a White-Russian one to document Bolsheviks massacres against the Orthodox church, and an American one to Ireland ${ }^{67}$.

One has to notice the contrast between the undisputable quality of the inquiries and the idealism or even naivety in the principles advocated by the Carnegie leadership. After all, the ultimate objective was nothing less than to defeat militarism and as the historian Geoffrey Best wrote, "the peace movement was swimming against the tide $»^{68}$. The concepts that education, implementation of international law and cultural internationalism would prevent further conflict illustrate the high confidence that the Carnegie men placed in the humankind.

Finally, one can ask if the Carnegie reports were only an expression of a humanitarian concern for civilians in warfare or a reflection of the new US foreign policy in Europe. The weight of the CEIP as powerful and influential network is to be emphasized. In the summer 1914 its Balkan Commission was ready to initiate a revision of the Berlin and Bucharest treaties. In the 1920s the scale of the reconstruction program undertaken in Central and Southeastern Europe showed that even if the State Department did not take the starting initiative, American foreign policy was de facto involved despite the refusal of the Congress to ratify the Versailles treaty and the US never joined the League of Nations. The ambiguous link and sometimes ill-defined relationship between non-profit organizations, such as the Carnegie Endowment and the US government increased further and played a substantial part in its foreign policy during the $20^{\text {th }}$ century. In conclusion, the Carnegie Endowment was a pioneer as it participated in redefining international affairs, institutionalizing the ideas and concepts elaborated by and through the pre-war Peace movement. 


\section{NOTES}

1. On the origins of the Peace movement, see the remarkable work undertaken by Holquist (Peter), The Russian Empire as a "Civilized State": International Law as Principle and Practice in Imperial Russia 1874-1878, Columbia : NCEEER Working Paper, 14/07/2004.

2. In 1899, 26 states were represented. In 1907, the number increased to 44 delegations.

3. The railroad network of the Balkans started in the 1870's. The Imperial Ottoman Bank (1863) was a French-British initiative within the modernization of the Ottoman Empire (Tanzimat).

4. Tensions between Christians and Muslims elements in Crete (1896-1899) and the rise of a national movement (IMRO) in Macedonia (1903) led to the implementation of two programs of international reforms (police/gendarmerie). The situation in Armenia (1895-1896) also led to a reform plan but its implementation remained much more limited.

5. Andrew Carnegie (1853-1919), originally from Scotland, made in fortune in the steel industry. He financed the building of the Court of Arbitration in The Hague (1907).

6. The board of trustees met in New York or Washington. A Year Book was published annually including the minutes of the meetings.

7. CEIP, Vol. 200, box 520, «Butler to d'Estournelles de Constant, Newport, July 21, 1913 ».

8. The New York Times, July 1-31, 1913, published 31 articles on Balkan Wars, most of them on the front page. Usually, one long piece followed by 3 to 5 shorter pieces.

9. CEIP, Vol. 200, box 520, "Carnegie to d'Estournelles de Constant, Skibo, September 18, 1913 ». From the letter, it seems that Carnegie was surprised to hear about the commission. Also, there is no indication of how the British newspaper reported about the commission's features.

10. The military forces have been estimated to one million (700 000 against 300000 Ottomans).

11. CEIP, Vol. 200, box 520, « Butler to d'Estournelles de Constant August 15, 1913 ».

12. CEIP, Vol. 200, box 520, « Haskell to d'Estournelles de Constant, July 28, 1913 ».

13. Carnegie Endowment for International Peace, Summary of Organization and Work, Washington, 1941, pp. 18-30 on the role of the Division of Intercourse and Education.

14. CEIP, Vol. 200, box 520, « d'Estournelles de Constant to Butler, Creans, August 6, 1913 ».

15. Dutton replaced Pr. Prince who despite his knowledge of Balkan languages excused himself for family reasons. On the French side, Victor Bérard's refusal led to Godart's nomination.

16. CEIP, Vol. 200, box 520, « Butler to d'Estournelles de Constant July 31, 1913 ».

17. CEIP, Vol. 121, « Dutton to Butler, Reading Ridge, Conn., July 23, 1913 ».

18. CEIP, Vol. 200, box 520, «Butler to d'Estournelles de Constant, September 22 and 29, 1913 ».

19. Butler and d'Estournelles de Constant discussed the language issue and mentioned that only Brailsford and Milioukov understood Slavic languages without naming specifically which one.

20. CEIP, Vol. 121, « Dutton to Butler, Sofia, September 20, 1913 ».

21. CEIP, Vol. 201, box 521, « Haskell to Prudhommeaux, December 12, 1913 ».

22. CEIP, Vol. 201, box 521, «Butler to d'Estournelles de Constant, December 12, $1913 »$; «d'Estournelles de Constant to Butler, January 6, 1914 » : «Je suis aussi ennuyé que vous par ce maudit rapport des Balkans. Milioukov s'est enseveli dans je ne sais quelle solitude de la Finlande pour terminer son travail ».

23. CEIP, Vol. 200, box 520, « Prudhommeaux to Haskell, Paris, October 17, 1913 ».

24. CEIP, Vol. 202, box 522, « Prudhommeaux to Haskell, Paris, May 12, 1914 ».

25. CEIP, Vol. 189, « Paper d'Estournelles de Constant, August 21, 1913 ».

26. University libraries of Belgrade and Louvain/Leuven and city library of Reims.

27. CEIP CE, box 44, « Butler to d'Estournelles de Constant, January 24, 1919 ».

28. CEIP, Vol. 141, box 480, « d'Estournelles de Constant to Butler, August 12, 1920 ». On E.Roots's visit to Paris and sharing ideas with Bourgeois. L.Bourgeois (1851-1925), French state-man, 
numerous times member of the government. Active member of the Peace Movement, French delegate at the two Hague Conferences, at the Peace Paris conference. Nobel Peace Prize in 1920. 29. CEIP CE, Vol.1, «Draft letter undated, Estournelles de Constant to Butler » : "Le jour où en 1920, la dotation Carnegie décida de compléter l'enquête (...) de reprendre notre oeuvre d'avant guerre et d'achever notre rapport dans les Balkans » (original in French).

30. CEIP CE, Vol. 190, «Prudhommeaux to d'Estournelles de Constant, May 23, 1919 ». Michel Kebedgy, international law professor and Alexander Antoniades, engineer, were part of the Greek delegation at the Peace Conference.

31. Ibid. Venizelos (1864-1936) has been several times prime minister of Greece (2 times in 1915 ; June 1917-Nov. 1920 ; Jan.-Feb. 1924 ; later in 1928-1932 and 1933) and a member of consultative committee at the Paris CEIP office. Andreas M. Andreades was sent officially to Washington to defend the Greek interests in the Balkans.

32. Ibid. The report does not mention if Reiss approach was made with the Serb official's approval. Archibald Reiss (1875-1929) is known for his report on Austro-Hungarian army atrocities against Serbians during WWI. He was part of the Serbian delegation at the Paris Peace Conference.

33. CEIP, Vol. 209, box 529, «Butler to d'Estournelles de Constant, December 22, 1919 ».

34. Vickers (Miranda), The Albanians, London : I.B. Tauris 2006, pp. 98-100. Some Yugoslav troops were in the Debar area since the end of WWI.

35. The Greek troops remained in the area until 1923.

36. Eleonore de Villa, the wife of Nouri Bey, general secretary at the Albanian foreign ministry, wrote directly several times to Butler. CEIP CE, Vol. 1 and 2 (vol.1 August 15, 1920, November 5, 1921).

37. Milenko Vesnić (1862-1921) was a diplomat and a professor of law. He was several times a member of the government Pašić and visited the USA during the war.

38. CEIP CE, Vol. 1, "d'Estournelles de Constant to Vesnitch, Creans, September 8, 1920 »; «d'Estournelles de Constant to Venizelos, Creans, September 8, 1920 ». He informed both men about the letters sent to Belgrade and Athens.

39. CEIP CE, Vol. 1, «d'Estournelles de Constant to Llyod George, Wilson, Millerand, Giolitti, Balfour, Paleologue, Berthelot, Creans, September 10, $1920 »$. (Answers from Paleologue on September 20, Lloyd Georges on October 5, Berthelot on October 26).

40. The telegrams were sent on October 5 and again on December 7, 1921.

41. Votes negative on December 1 and 4 : see Destani (Bejtullah), Tomes (Jason), eds., Albania's Greatest Friend, A. Herbert and the Making of Modern Albania. Diaries and Papers 1904-1923, New York: I.B. Tauris, 2011. p. 325.

42. CEIP, Vol. 142, box 480, « d'Estournelles de Constant to Butler, Paris, March 22, 1921 ».

43. CEIP, Vol. 141, box 480, « d'Estournelles de Constant to Butler, Paris, December 20, 1920 ».

44. According to our current research, there is no link between the CEIP and the London based group (Albanian Committee), but Robert Cecil (1864-1958) knew Bourgeois and A. Herbert (1880-1923). (Albania's Greatest Friend, idem).

45. CEIP, Vol. 142, box 480, « d'Estournelles de Constant to Butler, Paris, March 22, 1921 ».

46. Ibid.

47. Godart (Justin), L'Albanie en 1921, Paris : PUF, 1922, p. 99.

48. CEIP CE, Vol. 190, « Prudhommeaux to d'Estournelles de Constant, September 16, 1921 ».

49. CEIP, Vol. 146, box 482, « d'Estournelles de Constant to Butler, January 11, 1922 ».

50. Godart (Justin), op.cit., pp. 17-18: «Il me sembla toutefois, la Grande Guerre finie, qu'il convenait de compléter notre rapport de $1913 »$.

51. Maxim Kovalevsky (1851-1916), law professor, recommended Miliukov to d'Estournelles de Constant. CEIP vol. 200, box 520, d'Estournelles de Constant to Butler, August 1, 1913. 
52. Report of the International Commission to Inquire the Causes and Conducts of the Balkans Wars, Washington DC: CEIP 1914, pp. 79-83.

53. The words truth, impartiality, independence (press-, guaranty of-), objectivity appear about 25 times in both prefaces.

54. CEIP, Vol. 200, box 520, «Butler to d'Estournelles de Constant, October 7, 1913 ».

55. Report of the International Commission (op.cit.), pp. 247-253.

56. CEIP, Vol. 199, box 519, «Butler to d'Estournelles de Constant, December 2, 1912 »; «Prudhommeaux to Haskell, January 17, 1913 ». The II division is then considered for the inquiry.

57. The conference included France, Great Britain, Italy, Japan and USA as observer since the US congress had refused to ratify the Versailles Treaty. Meetings in Paris, Jan 1920-Nov-Dec1921.

58. Godart (Justin), op.cit., pp. 299-300. Asked by the League of Nations, the conference of the Ambassadors settled on St Naum and the Greek villages.

59. The Lake Mohonk Conference (1895-1916) was created to promote international arbitration. It gathered annually the elite of American power and influence.

60. Butler (Nicholas), The International Mind: An Argument for the Judicial Settlement of International Disputes, New York : C. Scribner's sons, 1912, p. 41.

61. Ibid, p. 102.

62. CEIP, Vol. 200, box 520, « Butler to d'Estournelles de Constant, August 15, 1913 ».

63. CEIP, Vol. 200, box 520, « Butler to d'Estournelles de Constant, July 31, $1913 »$.

64. CEIP, Vol. 141, box 480, « d'Estournelles de Constant to Butler, October 5, 1920 ».

65. See also Ulf Brunnbauer, Robert Bideleux, Holm Sundhaussen and even Edmund Glaise von Hostenau (in the first volume of his memories). Generally, English-speaking historians include the CEIP report more often than their German colleagues. The Carnegie Report was published in 1914, 1975-1977, and again in1993 with an introduction of G. Kennan.

66. However, the principle of sending international commission already happened in Armenia (1895-1896), and to a certain degree in Macedonia, 1904. In both cases, the investigations were conducted by diplomats or militaries representing the Great Powers.

67. Kévonian (Dzovinar), "L'enquête, le délit et la preuve: Les “atrocités" balkaniques à l'épreuve du droit de la guerre ", Le Mouvement Social, (222), 2008, pp. 23-24. The author includes a detailed list of investigative commissions sent after 1918.

68. Best (Geoffrey), Humanity in Warfare, New York : Columbia University Press, 1980, p. 131.

\section{RÉSUMÉS}

Among the significant features of the Carnegie Endowment for International Peace (CEIP) was not only the study of the causes but also of the impacts of the wars on civilian populations. In 1913, the CEIP sent an international commission to the Balkans. The result was the well-known report of 1914, the first widely circulated description on civilians in warfare. Seven years later, d'Estournelles de Constant, president of the CEIP Balkan Commission, sent a representative, Justin Godart to study the borders issues of Albania and to report on the crisis with Greece and Yugoslavia. Godart's report emphasized the continuity with the one of 1913 and pointed out how Albania was a key element in the stabilization of the Balkans.

Drawing from the Carnegie archives, the paper offers an innovative reading of CEIP's initiatives 
in the Balkans before and after World War I within the context of the last chapter of the Eastern Question.

Although both reports fell short of their objectives as the one of 1914 coincided with the onset of the war and the fragile conditions of the new states post 1918 prevented the success of the second one; the principles of stabilization, integration and economic prosperity were visionary as they are still "on the table" in the Balkans today.

\section{INDEX}

Keywords : Balkans, Carnegie Endowment, Civilians in Warfare, International Intervention., International Law

\section{AUTEUR}

\section{NADINE AKHUND}

IRICE, Paris I (Identities, International Relations and European Civilizations 3 First Place, 11231, Brooklyn, New York, USA

Tel: 7188582608

E-mail: Nadine.akhund@gmail.com 